\title{
Further considerations about the ophthalmic features of the Möbius sequence, with data of 28 cases
}

\author{
Novas considerações sobre oquadroclínico da seqüência de Möbius \\ com dados de 28 casos
}

\author{
Carlos Ramos de Souza-Dias ${ }^{1}$ \\ Mauro Goldchmit ${ }^{2}$
}

\footnotetext{
Trabalho realizado na Faculdade de Ciências Médicas da Santa Casa de São Paulo - São Paulo (SP) - Brasil.

${ }^{1}$ Livre Docente, Professor Titular do Departamento de Oftalmologia da Faculdade de Ciências Médicas da Santa Casa de São Paulo - São Paulo (SP) - Brasil.

${ }^{2}$ Doutor, Chefe do Setor de Estrabismo do Departamento de Oftalmologia da Santa Casa de São Paulo - São Paulo (SP) - Brasil.

Endereço para correspondência: Carlos R. SouzaDias. Rua Cincinato Braga, 59 - Conj. 5 - B2 - São Paulo (SP) CEP 01333-011

Recebido para publicação em 13.05.2006

Última versão recebida em 14.12.2006

Aprovação em 16.01.2007

Nota Editorial: Depois de concluída a análise do artigo sob sigilo editorial e com a anuência da Dra. Mônica Fialho Cronemberger sobre a divulgação de seu nome como revisora, agradecemos sua participação neste processo.
}

\begin{tabular}{|c|}
\hline ABSTRACT \\
\hline 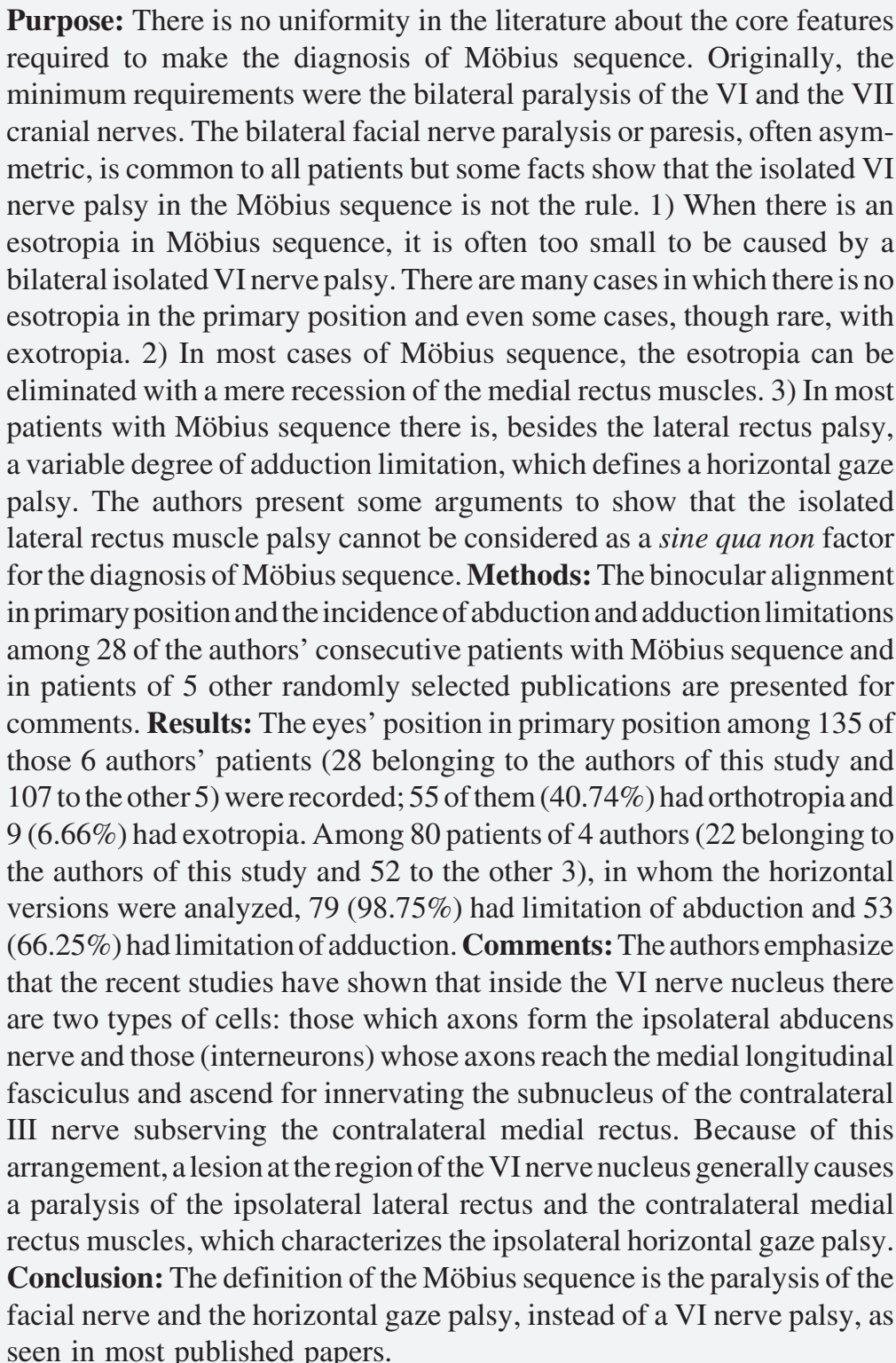 \\
\hline
\end{tabular}

Keywords: Mobius syndrome/diagnosis; Facial paralysis/congenital; Eye diseases 


\section{INTRODUCTION}

In the late XIX century, some authors reported a few isolated cases of associated paralysis of the VI and the VII cranial nerves $^{(1-3)}$. In 1888, Paul Julius Möbius ${ }^{(4-5)}$, a German neurologist, collected 6 cases of this pathologic entity, which later came to be called Möbius syndrome. In some of their cases they reported also a paralysis of the conjugated horizontal eye movements (horizontal gaze palsy).

Originally, this clinical picture was known as Möbius syndrome, but some syndrome experts, based on sound arguments, prefer the term Möbius sequence.

Classically, the Möbius sequence is accompanied by other congenital systemic abnormalities, as in the tongue, teeth, mandible, limb extremities, thorax muscle (Poland's anomaly Figure 1B) etc., besides some mental anomalies, as autism. It is congenital, spontaneous or consequent to drug ingestion and, though rare, it may have a genetic origin.

There is no uniformity in the literature about the core features required to make the diagnosis of Möbius sequence. Originally, the minimum requirements were the bilateral paralysis of the VI and the VII cranial nerves. Miller \& Strömland ${ }^{(6)}$ state that it seems inappropriate not to include the VI nerve involvement, because that is what Möbius described. The bilateral facial nerve paralysis or paresis, often asymmetric, is common to all patients but some facts show that the isolated VI nerve palsy (isolated lesion of the specific VI nerve nuclear cells) in the Möbius' sequence is not the rule.

1) When there is esotropia in Möbius sequence, it is often too small to be caused by a bilateral isolated VI nerve palsy, which causes always a very large angle esotropia. We have seen many cases in which there is no esotropia in the primary position (Figure 2A) and even some cases, though rare, with exotropia (Figure 3), which coincides with the series of other authors $^{(6-9)}$. It is difficult to imagine an exotropia or even an orthotropia in the presence of an isolated paralysis of the lateral recti. We cannot agree with Henderson's ${ }^{(10)}$ statement that "...it was noted that convergent squint was not present in about half of the instances of abducens paralysis".

2) In most cases of Möbius sequence the esotropia can be eliminated with a mere recession of the medial rectus muscles, which frequently shows reduced elasticity, independently of the size of the esotropia. It is well known that a bilateral recession of the medial rectus alone cannot align the eyes in cases of lateral rectus paralysis of other etiologies. The stiffness of the medial rectus muscles is difficult to explain in some patients with small angle esotropias; obviously it is not a contracture secondary to lateral rectus palsy, for in this case the contracture is caused by the marked and longstanding adduction of the eye bulb.

3) In most patients with Möbius sequence we have seen, besides the lateral recti palsy, a variable degree of adduction limitation, sometimes asymmetric, which defines horizontal gaze palsy.
We present in this article some arguments to show that the isolated VI nerve palsy (isolate lateral rectus muscle paralysis) cannot be considered as a sine qua non factor for the diagnosis of Möbius sequence.

\section{METHODS}

The binocular alignment in primary position and the incidence of abduction and adduction limitations among 28 of our consecutive patients with Möbius sequence and in patients of 5 other randomly selected publications are presented for comments ${ }^{(6-10)}$ (Tables 1 and 2).

\section{RESULTS}

Of 28 of our consecutive patients with Möbius sequence, 17 had esotropia (60.7\%), 10 orthotropia (35.7\%) and 1 exotropia (3.6\%) in primary position (Table 1). Among 22 of the 28 patients, in whom the lateroversions were carefully studied (Table 2), 10 (45.5\%) had limitation of abduction and adduction (horizontal gaze palsy) with no esotropia or small angle esotropia, 9 had only limitation of abduction (40.9\%), and 3 had absolute limitation of abduction with very large angle esotropia (13.6\%), which rendered impossible the observation of the adduction.

Henderson $^{(10)}$ reported 61 patients of Möbius sequence, 45 of whom (73.8\%) showed abducens palsy (Table 2); of these forty five, 23 showed convergent squint $(51.1 \%)$ and 22 had straight eyes $(48.9 \%)$ (Table 1$)$.

In the series of 18 cases of Möbius sequence of Amaya et al. ${ }^{(8)}, 14$ patients had esotropia $(77.8 \%), 2$ patients had orthotropia (11.1\%) and 2 patients had exotropia (11.1\%) (Table 1). They all had limited or absent abduction, and adduction was absent in 9 (50\%) (Table 2). These 9 patients had total horizontal gaze palsy.

Among 28 patients of Santos et al. ${ }^{(9)}$, sixteen had esotropia $(57.2 \%), 7$ had orthotropia (25.0\%), 2 had exotropia $(7.1 \%)$ and $3(10.7 \%)$ only hypertropia (Table 1$)$. Abduction was limited in all cases (Table 2). The authors do not report the number of patients with adduction limitation, but they state that the medial rectus muscles were underacting in an average of $-2,6 \pm$ $1,4 \mathrm{OD}$ and $-2.5 \pm 1.5 \mathrm{OS}$, from 0 to -4 in both eyes.

Among 16 patients of Cronemberger et al. ${ }^{(7)}$, esotropia was present in $12(75 \%)$, exotropia in $2(12.5 \%)$ and orthotropia in 2 (12.5\%) (Table1). Limited abduction was present in 15 patients (93.8\%) and limited adduction in 11 patients (68.6\%) (Table 2). The degree of adduction limitation was very variable.

Analyzing the data of Miller and Strömland ${ }^{(6)}$, we could conclude the following: of 21 patients who did not undergo strabismus surgery, 7 were esotropic (33.3\%), 2 were exotropic $(9.5 \%), 8$ were orthotropic $(38.1 \%)$ and 3 were grossly straight $(14.3 \%)$, In one patient there was only a hypertropia in the primary position $(4.8 \%$ ) (Table 1$)$. In all patients but one, who 


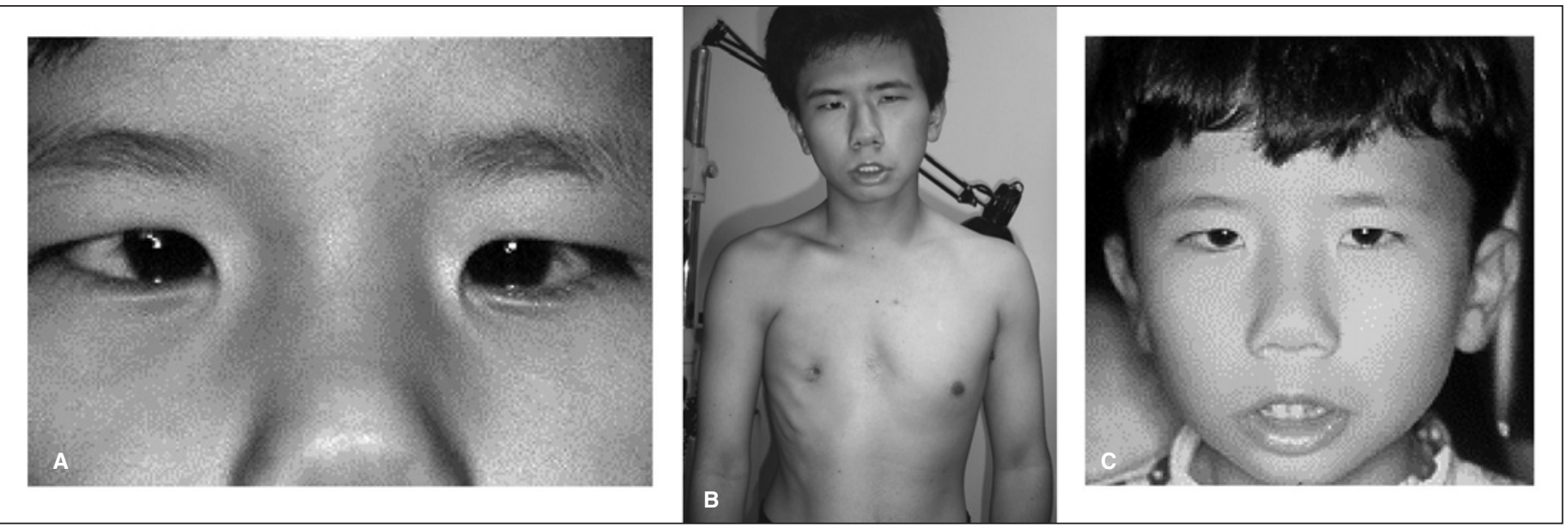

Figure 1 - Patient with Möbius sequence with Poland anomaly (B); he had a very large angle esotropia and a recession of both medial rectus muscles did not change the eyes' positions, a lateral transposition of the vertical rectus muscles was necessary in order to correct it $(A)$. These results suggest that the medial rectus muscles are much less affected than the lateral ones.

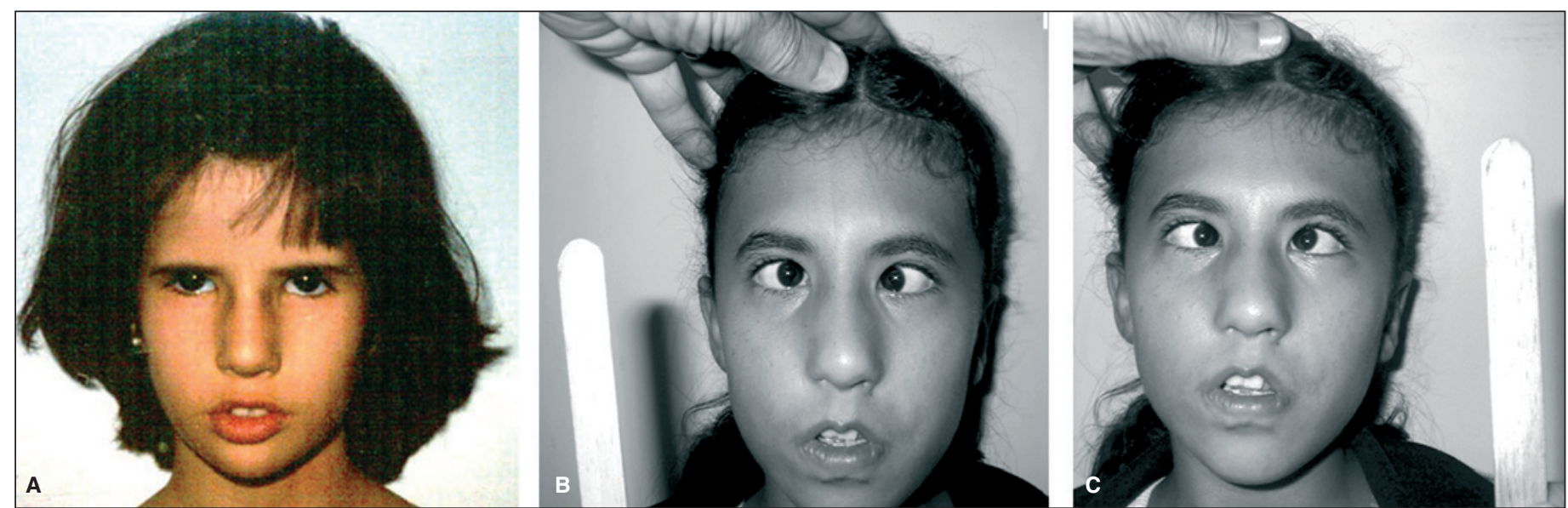

Figure 2 - Patient with Möbius sequence with orthotropia in primary position (A) and convergence instead of lateroversion (B and C). In B, she makes a convergence with her right eye to look at an object placed at her left side; in $C$, she makes a convergence with her left eye to look at an object placed at her right side. The orthotropia shows that there is a perfect equilibrium between adducting and abducting forces.

was grossly straight in primary position, the authors were able to get reliable examination of the horizontal versions. Most esotropic patients had more decreased abduction than adduction; the 2 patients with exotropia showed greater adduction than abduction deficits. A common pattern was straight or nearly straight alignment in primary position with greatly decreased abduction and adduction. Among the 22 patients who did not undergo strabismus surgery and in whom the horizontal version movements could be reliably examined, abduction was limited in all of them, varying from -1 to -5 , and adduction was limited in 21 patients $(95.5 \%)$, varying from -1 to -3 ; thus adduction was normal in one patient (4.5\%), who was esotropic.

\section{COMMENTS}

Among 28 of our consecutive patients with Möbius sequence, there were 17 with esotropia (60.7\%), 10 with ortho- tropia (35.7\%) and 1 with exotropia (3.6\%) in the primary position (Table 1). Therefore at least $11(39.3 \%)$ of them could not have isolated VI nerve paralysis (orthotropic and exotropic patients). Among 22 of the 28 patients in whom the lateroversions could be carefully studied, 9 had only limitation of abduction (40.9\%) (predominantly abducens nerve paralysis or paresis), 10 had limitation of abduction and adduction with no esotropia or small angle esotropia (45.5\%) (lateral and medial recti grossly equally affected) and 3 had absolute limitation of abduction with large angle esotropia $(13.6 \%)$, which obstructed the examination of adduction (isolated lateral rectus palsy, horizontal gaze palsy with total paralysis of the lateral rectus and slight loss of the medial rectus force, or fibrosis with shortness of this one?) (Table 2).

Henderson ${ }^{(10)}$ reported 61 cases of Möbius sequence, 45 of which (73.8\%) showed abducens palsy; of these forty five patients, 23 showed convergent squint $(51.1 \%)$ and 22 had 


\begin{tabular}{|c|c|c|c|c|c|c|}
\hline Authors & $\mathbf{N}$ & $\begin{array}{c}\text { ET } \\
\text { N (\%) }\end{array}$ & $\begin{array}{c}\text { XT } \\
\text { N (\%) }\end{array}$ & $\begin{array}{l}\text { Ortho } \\
\text { N (\%) }\end{array}$ & $\begin{array}{c}\text { Gros. straight } \\
\text { N (\%) }\end{array}$ & $\begin{array}{c}\text { HT } \\
\text { N (\%) }\end{array}$ \\
\hline Souza-Dias \& Goldchmit & 28 & $17(60.7)$ & $1(3.6)$ & $10(35.7)$ & - & - \\
\hline Amaya et al. ${ }^{(8)}$ & 18 & $14(77.8)$ & $2(11.1)$ & $2(11.1)$ & - & - \\
\hline Santos et al. ${ }^{(9)}$ & 28 & $16(57.2)$ & $2(7.1)$ & $7(25.0)$ & - & $3(10.7)$ \\
\hline Cronemberger et al. ${ }^{(7)}$ & 16 & $12(75.0)$ & $2(12.5)$ & $2(12.5)$ & - & - \\
\hline Miller et al. ${ }^{(6)}$ & 21 & 7 (33.3) & $2(9.5)$ & $8(38.1)$ & $3(14.3)$ & $1(4.8)$ \\
\hline Henderson ${ }^{(10)}$ & $45^{(*)}$ & $23(51.1)$ & - & $22(48.9)$ & - & - \\
\hline
\end{tabular}

\begin{tabular}{|c|c|c|c|}
\hline Authors & $\mathbf{N}$ & $\begin{array}{l}\text { Lim. } \\
\text { abduction } \\
\mathbf{N}(\%)\end{array}$ & $\begin{array}{c}\text { Lim. } \\
\text { adduction } \\
\mathrm{N}(\%)\end{array}$ \\
\hline Souza-Dias \& Goldchmit & 22 & $22(100.0)$ & $10(45.5)$ \\
\hline Amaya et al. ${ }^{(8)}$ & 18 & $18(100.0)$ & $9(50.0)$ \\
\hline Santos et al. ${ }^{(9}$ & 28 & $28(100.0)$ & $\left({ }^{*}\right)$ \\
\hline Cronemberger et al. ${ }^{(7)}$ & 16 & $15(93.8)$ & $11(73.3)$ \\
\hline Miller et al. ${ }^{(6)}$ & 24 & $24(100.0)$ & $23(95.8)$ \\
\hline Henderson ${ }^{(10)}$ & 61 & $45(73.8)$ & $\left({ }^{*}\right)$ \\
\hline
\end{tabular}

straight eyes $(48.9 \%)$. But the author did not make any reference to the associated limitations of abducting and adducting movements.

Among 16 patients of Cronemberger et al. ${ }^{(7)}$, esotropia was present in $12(75 \%)$ (Table 1), limited abduction was present in 30 eyes $(93.8 \%)$ and limited adduction in 22 eyes $(73.3 \%)$ (Table 2), which means that, theoretically, $65.6 \%$ of the eyes had horizontal gaze palsy (limited abduction and adduction) and $28.2 \%$ had isolated lateral rectus palsy or a very slight paresis of the medial rectus (only abduction was affected) (Table 2).

In the series of 18 patients of Amaya et al.'s Möbius sequence $^{(8)}, 14$ had esotropia (77.8\%), 2 patients had orthotropia $(11.1 \%)$ and 2 patients had exotropia $(11.1 \%)$ (Table 1); therefore at least $22.2 \%$ of them could not have isolated VI nerve palsy.

Among 28 patients of Santos et al. ${ }^{(9)}, 16$ patients had esotropia $(57.2 \%), 7$ had orthotropia $(25.0 \%), 2$ had exotropia $(7.1 \%)$ and 3 had only hypertropia $(10.7 \%)$ (Table 1$)$; therefore at least $42.8 \%$ of them could not have isolated VI nerve palsy (patients with orthotropia, exotropia and only hypertropia).

The comprehensive description of the 22 patients of Miller and Strömland ${ }^{(6)}$ is very important for the understanding of the eye motility of the patients with Möbius sequence. The primary position situation in the 22 patients who had no strabismus surgery was the following: seven were esotropic (33.0\%), 8 were orthotropic (38.1\%), 2 were exotropic (9.5\%), 3 were "grossly straight" (14.3\%) and one had only a hypertropia (4.8\%), which leads to the conclusion that $59.1 \%$ of them

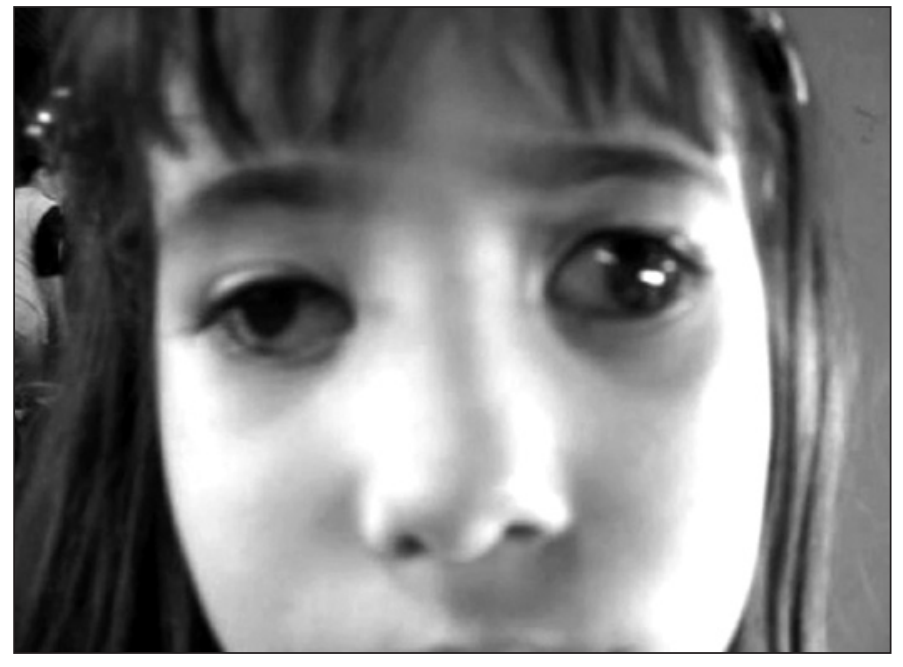

Figure 3 - Patient with Möbius sequence with exotropia in primary position. The exotropia shows that abduction is less affected than adduction.

had no horizontal deviation in primary position (Table 1). Hence, excluding the seven esotropic patients, these 15 last ones ( $68.2 \%$ of the 22 patients) could not have isolated VI nerve paralysis. According to the authors, among the patients in whom it was possible to examine the horizontal versions, most esotropic patients had more decreased abduction than adduction; the 2 patients with exotropia showed greater adduction than abduction deficits. A common pattern was straight or nearly straight alignment in primary position with greatly decreased abduction and adduction. Among 24 patients in whom the horizontal versions movements could be reliably examined, abduction was limited in all of them, varying from -1 to -5 , and adduction and abduction was limited in 23 patients $(95.8 \%$ ), varying from -1 to -3 (Table 2 ); thus adduction was normal in one patient $(4.2 \%)$. It is possible to conclude from these data: 1 . In most of their cases of Möbius sequence there is a horizontal gaze palsy; 2 . The eyes' alignment in primary position of their patients depended on the state of balance of the adducting and abducting forces.

As aforementioned, in a great number of cases diagnosed as Möbius' sequence, there is a paralysis (or paresis) of the conjugated horizontal movements (gaze palsy). It means that, in the attempt of lateroversion, both the ipsolateral lateral 
rectus and the contralateral medial rectus are not innervated (or partially innervated).

Schapringer ${ }^{(11)}$, in 1889 , described a girl with congenital facial paralysis and inability to rotate the eyes laterally. He proposed for this entity the adequate name of pleuroplegia ( pleura in Greek means side + plegia $=$ stroke, blow).

Modern studies have shown that there is not a supranuclear center of laterality, similar to the intermediate supranuclear center of the vertical movements, situated at the rostral portion of the pons, near the quadrigeminal plate and the pineal body. It may be said that the center of the conjugate horizontal movements lies in the pontine VI nerve nucleus, so the nervous influx coming from the contralateral cerebral cortex stimulates directly the nuclear cells. Studies have demonstrated that in the VI nerve nucleus there are two kinds of cells: those which axons, emerging from its medial aspect, form the roots of the ipsolateral abducens nerve and those which axons reach the medial longitudinal fasciculus and ascend for innervating the subnucleus of the contralateral III nerve subserving the contralateral medial rectus ${ }^{(12)}$. Because of this arrangement, a lesion at the region of the VI nerve nucleus generally causes a paralysis of the ipsolateral lateral rectus and the contralateral medial rectus (ipsolateral horizontal gaze palsy $)^{(13-14)}$. Similarly to what occurs in anterior internuclear ophthalmoplegia, the contralateral medial rectus contracts with the convergence impulse, because the neural paths for convergence are different of the ones for versional movements. However, according to Carpenter ${ }^{(15)}$, for the Möbius sequence to occur a total destruction of the VI nerve nucleus is not necessary, but the involvement of its ventral portions seems critical. The author deduces from this fact that a selective nuclear paralysis of the ipsolateral lateral rectus is theoretically possible, which seems to be the case of some of the aforementioned patients who present normal adduction or a very large esotropia.

It has been postulated that cells in the reticular formation adjacent to the abducens nucleus may give rise to fibers destined to the conjugated horizontal movements ${ }^{(16)}$, which would compose a paranuclear intermediate center of horizontal gaze movements. Beck \& Smith ${ }^{(13)}$ make reference to a paraabducens nucleus with this same function. But this theory is not sufficiently proved.

It seems that the most probable cause of the absence of adduction and abduction in the Möbius sequence is a widespread lesion or maldevelopment of the VI nerve nucleus (gaze palsy). Electromyographic evidence for this origin of the defect was contributed by van Alen and Blodi (1960) ${ }^{(17)}$ and several investigators have reported images of bilateral pontine calcifications or hypoplasia at the region of the fourth ventricle floor, at the level of the VI and the VII nerve complexes (facial colliculus or eminentia teres) ${ }^{(18-21)}$ in patients with Möbius sequence.

When the cells of the VI nerve nucleus subserving the lateral rectus of the ipsolateral eye and the interneurons of the contralateral VI nerve nucleus subserving the medial rectus of this same eye are equally injured, the paralysis of the medial rectus may hide the lateral rectus palsy, avoiding the emergence of the large esotropia that usually can be seen in most lateral rectus paralysis of other etiologies. This fact can explain the cases of Möbius sequence with orthotropia in primary position. As to the cases with exotropia, there may be two explanations: 1) the interneurons of the contralateral VI nerve nucleus responsible for the medial rectus are more affected than the cells of the ipsolateral VI nerve nucleus destined to the lateral rectus; 2) the lesion lies in the medial longitudinal fasciculus, interrupting the axons of the interneurons of the contralateral VI nerve nucleus subserving the medial rectus, a fact observed by Heubner ${ }^{(22)}$. Yet the VI nerve nucleus is in the vicinity of the medial longitudinal fasciculus, which allows a simultaneous lesion of both structures. Most cases of isolated paralysis of the abducens nerve with a great angle esotropia of other etiologies are caused by lesions at the nerve trunk, not at the nucleus, like in diabetes mellitus ${ }^{(23)}$ and in cranial traumatism ${ }^{(24)}$.

The predominance of esotropia in the Möbius sequence seems to show that the VI nerve cells are more exposed to injury than the medial rectus interneurons; the equal lesion of both kinds of cells comes second to frequency (orthotropia) and the predominance of lesion of the interneurons for the medial recti is rare (exotropia). The observation of these patients shows that, while the lateral rectus is paralytic as a rule, or intensively paretic, the degree of weakness of the medial rectus is more variable, from very light to total, not only among patients but also between the eyes of the same patient, which means that the extension of the lesion of the nuclear cells is variable.

There is an interesting phenomenon that we have observed in some of our patients with this sequence, already described by Möbius ${ }^{(4)}$ in one of his patients of his first article and later by other authors ${ }^{(6)}$, which shows clearly the presence of gaze palsy: the convergence instead of lateroversion.

Description of case: A 10-year-old girl, African descendant; her mother reported that since birth she has no facial mimic movements and cannot move her eyes laterally. Except for those anomalies, she did not have any other important systemic or ophthalmic health problem. Her visual acuity was $20 / 25$ in both eyes with small degree hyperopia. Besides the peripherical symmetric bilateral paralysis of the facial nerves, the eye motility examination showed a conjugate paralysis of the horizontal movements, with orthotropia in primary position. When insistently stimulated to look at an object positioned at one of her sides, without turning the head, she did a convergence in order to look at the object with the contralateral eye (Figure 2). The accommodation induced by the voluntary convergence (proximal reflex) allowed her to see the object focused and there was a pupil constriction, the third component of the near reflex.

One of the Möbius patients(4) was an adult who had the eyes in normal position (sic) but lateral movements were absent; however, adduction could be obtained on command to 
follow an object with one eye covered. He found that that movement was part of a convergence, since the covered eye adducted as well.

It is important to note that in the Möbius sequence the reflex eye movements induced by vestibular stimulation are also absent, because the vestibulo-ocular axons stimulate directly the nerves nucleus' cells.

There are some rare cases of Möbius sequence in which there is, besides the facial diplegia, an apparent selective paralysis of the lateral recti with a very large angle esotropia. However, in these cases there is almost always a strong inelasticity of the medial rectus. Is it caused by the longstanding adduction of the eyes caused by a lateral rectus paralysis or is it a primary structural alteration of the medial rectus structure? The frequent and not satisfactorily explained inelasticity and shortness of this muscle, so frequently found during the surgery of Möbius sequence, may be the cause of the esotropia. The possibility of structural anomalies of the eye muscles in Möbius sequence was demonstrated by Traboulsi \& Maumenee ${ }^{(25)}$, Stansbury ${ }^{(26)}$, Meyer et al. ${ }^{(27)}$, Torres et al. ${ }^{(28)}$, Reed \& Grant $^{(29)}$, Rodrigues-Alves \& Caldeira ${ }^{(30)}$ and others; they found both medial and lateral fibrotic recti in cases of this sequence. In fact, we have seen in some cases that the lateral rectus muscle is also inelastic at variable degrees. The pathogeny of this anomaly is not explained yet.

The cases of selective abducens nerve palsy require transpositions of the vertical recti in order to align the eyes ${ }^{(31-33)}$ (Figure 1A), but when the pathogenesis of the esotropia is the shortness and inelasticity of the medial rectus, a simple recession of this muscle can repair it, as one of the authors had demonstrated elsewhere ${ }^{(24)}$. This difference is quite difficult to be recognized preoperatively. As aforesaid, this medial recti inelasticity in Möbius sequence can be seen even in patients with small angle esotropia.

Amaya et al. ${ }^{(8)}$ established as the minimal criteria for the diagnosis of Möbius sequence the presence of a selective unilateral or bilateral congenital seventh nerve paresis combined with sixth nerve paresis "or" horizontal gaze palsy; Spierer et al ${ }^{(33)}$ state that "Möbius syndrome is a congenital disorder of facial diplegia associated with lateral gaze paralysis".

On the other hand, some other authors do not even make a reference to the possibility of horizontal gaze palsy. In the articles of 11 randomly chasen ${ }^{(7-10,13,17,28,34-37)}$ authors, all but one reported only the existence of VI nerve palsy in their patients who related gaze palsy ${ }^{(17)}$. Elsahy ${ }^{(36)}$, for instance, defines the Möbius sequence as "facial paralysis, lateral rectus muscle paralysis, anomalies of the extremities ..."; however, in the description of his case, he reports the absence of conjugate horizontal movements. Torres ${ }^{(28)}$ defines the Möbius sequence as a paralysis of the sixth and seventh cranial pairs; but in the description of his case he reports large angle esotropia without movements in the horizontal plane. Sogg ${ }^{(35)}$ states that "The Möbius syndrome consists of congenital facial diplegia usually associated with bilateral abducens nerve palsy". But Duke-
Elder $^{(38)}$ already in 1949, stated about Möbius sequence that "in a typical case...lateral movements of the eyes both in adduction and abduction are impossible...".

\section{CONCLUSIONS}

Based on these considerations, we suggest to be considered that the core features required to make the diagnosis of Möbius sequence are a bilateral symmetrical or asymmetrical paralysis of the facial nerves (in a few cases it can be unilateral) and horizontal gaze palsy, with usually marked bilateral abduction limitation and a variable limitation of adduction.

\section{RESUMO}

Objetivo: Não há uniformidade na literatura sobre as anomalias necessárias para caracterizar a seqüência de Möbius. Originalmente, os requisitos mínimos eram a paralisia do VI e do VII nervos cranianos. A paralisia facial bilateral, às vezes assimétrica, é comum a todos os pacientes, mas alguns fatos mostram que a paralisia isolada do VI nervo não é a regra.1) Quando há esotropia na sequiência de Möbius, é muitas vezes muito pequena para ser causada por paralisia bilateral do VI nervo. Há muitos casos que não apresentam esotropia ou mesmo, embora raramente, têm exotropia. 2) Em muitos casos a esotropia pode ser eliminada com apenas o retrocesso dos retos mediais. 3) Em muitos desses pacientes há, além da limitação de abdução, também limitação de adução, o que define a paralisia conjugada dos movimentos horizontais. Os autores apresentam argumentos para mostrar que a paralisia isolada dos retos laterais não pode ser considerada condição sine qua non para o diagnóstico da sequiência de Möbius. Métodos: $\mathrm{O}$ alinhamento binocular em posição primária e a incidência de limitação de abdução e adução entre 28 dos casos consecutivos de seqüência de Möbius dos autores e entre os casos de 5 outros autores eleitos aleatoriamente são apresentados para comentários. Resultados: As posições binoculares em posição primária de 135 pacientes desses 6 autores ( 28 pertencentes aos autores deste trabalho e 107 dos outros 5) foram anotadas; 55 pacientes $(40,74 \%)$ tinham ortotropia e $9(6,66 \%)$ tinham exotropia. Entre 80 pacientes de 4 autores ( 22 pertencentes aos autores e 107 dos outros 3), nos quais as versões horizontais foram estudadas, $79(98,75 \%)$ apresentavam limitação de abdução e $53(66,25 \%)$ tinham limitação de adução. Comentários: Os autores enfatizam o fato de que estudos recentes têm demonstrado que no interior do núcleo do VI nervo existem dois tipos de células: as que formam o nervo abducente ipsolateral e as que, cruzando através do fascículo longitudinal medial, atingem o subnúcleo do III nervo contralateral destinado à inervação do reto medial contralateral.

Descritores: Sindrome de Möbius/diagnóstico; Paralisia facial/congênito; Oftalmopatias 


\section{REFERENCES}

1. Chisolm JJ. Congenital paralysis of the sixth and seventh pairs of cranial nerves in an adult. Arch Ophthalmol. 1882;11:323-5.

2. Harlan GC. Congenital paralysis of both abducens and both facial nerves. Trans Am Ophthalmol Soc. 1881;3:216-8.

3 Von Graefe A, Saemisdi T. Handibuch der Gesamten Augenheilkunde. Leipzig: Wilhelm Engelman; 1880. p. 60-1

4. Möbius PJ. [Uber angeborene doppelseitige Abducens-Facialis-lähmung]. Munch Med Wochenschr. 1888;35:91-4. German.

5. Möbius PJ. [Uber infantile Kernschwund]. Munch Med Wochenschr. 1892; 39:17-58. German.

6. Miller MT, Stromland K. The mobius sequence: a relook. J AAPOS. 1999; 3(4):199-208.

7. Cronemberger MF, de Castro Moreira JB, Brunoni D, Mendonça TS, Alvarenga EH, Rizzo AM, Diogo SM. Ocular and clinical manifestations of Mobius' syndrome. J Pediatr Ophthalmol Strabismus. 2001;38(3):156-62.

8. Amaya LG, Walker J, Taylor D. Möbius syndrome: a study and report of 18 cases. Binocul Vis Q. 1990;5:119-32.

9. Santos LPF, Ventura LMVO, Almeida HC, Miller M, Colier AC. Achados oftalmológicos em 28 crianças portadoras da seqüência de Möebius. Arq Bras Oftalmol. 2004;67(4):591-5.

10. Henderson JL. The congenital facial diplegia syndrome: clinical features, pathology and aetiology: a review of sixty-one cases. Brain. 1939;62(4):381-403.

11. Schapringer A. Congenital bilateral abducens paralysis with facial paralysis. Boston Med Surg J. 1889;121:635.

12. Leigh RJ, Zee DS. The neurology of eye movements. $3^{\text {rd }}$ ed. New York: Oxford University Press; 1999. p. 331.

13. Beck RW, Smith CH. Neuro-ophthalmology: a problem oriented approach. Boston: Little-Brown; 1988. p. 199.

14. Carpenter MB, Batton RR $3^{\text {rd }}$. Abducens internuclear neurons and their role in conjugate horizontal gaze. J. Comp Neurol. 1980;189(1):191-209.

15. Carpenter MB. Central oculomotor pathways. In: Bach-y-Rita P, Collins CC, Hyde JE,editors. The control of eye movements. New York: Academic Press; 1971. p. 67-104.

16. Truex RC, Carpenter MB. Human neuroanatomy. $6^{\text {th }}$ ed. Baltimore: Williams \& Wilkins; 1969. p. 360-1.

17. Van Alen MW, Blodi FC. Neurologic aspects of the Mobius syndrome. A case study with electromyography of the extraocular and facial muscles. Neurology. 1960;10:249-59.

18. Ouanounou S, Saigal G, Birchansky S. Mobius syndrome. AJNR Am J Neuroradiol. 2005;26(2):430-2.
19. Kuhn MJ, Clark HB, Morales A, Shekar PC. Group III Mobius syndrome: CT and MR findings. AJNR Am J Neuroradiol. 1990;11(5):903-4.

20. D'Cruz OF, Swisher CN, Jaradeh S, Tang T, Konkol RJ. Mobius syndrome: evidence for a vascular etiology. J Child Neurol. 1993; 8(3):260-5.

21. Pedraza S, Gamez J, Rovira A, Zamora A, Grive E, Raguer N, Ruscalleda J. MRI findings in Mobius syndrome: correlation with clinical features. Neurology. 2000;55(7):1058-60.

22. Heubner O. [Über angeborenen Kernmangel]. Charite Ann. 1900;25:211-43. German.

23. Asbury AK, Aldredge H, Hershberg R, Fisher CM. Oculomotor palsy in diabetes mellitus: a clinico-pathological study. Brain. 1970;93(5):555-66.

24. Prieto-Díaz J, Souza-Dias C. Estrabismo. 5. ed. Buenos Aires: Ediciones Científicas Argentinas. 2005. p. 354. achei 4.ed. São Paulo: Livraria Santos Editora; 2002.

25. Traboulsi EI, Maumenee IH. Extraocular muscle aplasia in Moebius syndrome. J Pediatr Ophthalmol Strabismus. 1986;23(3):120-2.

26. Stansbury JR. Moebius's syndrome; congenital oculofacial paralysis: a case report. Am J Ophthalmol. 1952;35(2):256-61.

27. Meyer E, Ludatscher RM, Zonis S. Mobius syndrome. Electron microscopic study of the extraocular muscles. Ophthalmic Paediatr Genet. 1984;4(2):91-5.

28. Torres RJA, Ferreira AA, Federmann I, Burnier Júnior MNN. Dois casos de Síndrome de moebius: associação com catarata e achados histopatológicos. Arq Inst Penido Burnier. 1986;28(1):35-8.

29. Reed H, Grant W. Mobius syndrome. Br J Ophthalmol. 1957;41(12):731-40.

30. Rodrigues-Alves CA, Caldeira JAF: Moebius syndrome: a case report with multiple congenital anomalies. J Pediatr Ophthalmol. 1975;12(2):103-6.

31. Hicks AM. Congenital paralysis of lateral rotators of eyes with paralysis of muscles of face. Arch Ophthalmol. 1943;30:38-42.

32. Laby DM, Rosenbaum AL, Isemberg SJ, Fleck BW. Strabismus surgery in patients with Moebius syndrome. In: Lennerstrand G, editor. Update on strabismus and pediatric ophthalmology. Boca Raton, FL: CRS Press; 1995. p. 419-22.

33. Spierer A, Barak A. Strabismus surgery in children with Mobius syndrome. J AAPOS. 2000;4(1):58-9

34. Magnani AC, Prietsch RF, Araújo AL. Síndrome de Möbius: relato de dois casos com apresentações clínicas diferentes. Arq Bras Oftalmol. 2005;68(4 Supl):91.

35. Sogg RL. Congenital facial diplegia syndrome of Möbius. Arch Ophthalmol. 1961;65:4.

36. Elsahy NI. Moebius syndrome associated with the mother taking thalidomide during gestation. Case report. Plast Reconstr Surg. 1973;51(1):93-5.

37. Von Noorden GK, Campos EC, editors. Binocular vision and ocular motility: theory and management of strabismus. $6^{\text {th }}$ ed. St. Louis: Mosby; 2002. p. 440-3.

38. Duke-Elder WS. Textbook of ophthalmology. London: Henry Kimpton; 1949. p. 4093.

\section{Ao enviar um artigo para publicação,} leia ATENTAMENTE as instruções para autores, constante no final de cada fascículo. 